3. The antibiotics of the cephalosporins and aminoglycosides groups are effective as etiotropic therapy in treating dogs from leptospirosis.

Further studies will be focused on the effects of certain serotypes of Leptospira on the organs of dogs at Leptospira monoinfection and the mixed infection of leptospirosis with babesiosis.

Keywords: leptospirosis, dogs, epizootology, diagnostics, treatment.

\title{
REFERENCES
}

1. Bernasovs'ka, S.P. et al. (1996). Problema leptospirozu v Ukraini [The problem of leptospirosis in Ukraine]. Infekcijni hvorobi-Infectious diseases, 2, 37-39 [in Ukrainian].

2. Zadorozhna, V.I. et al. (2014). Epizootologichni ta epidemiologichni aspekti leptospirozu $v$ Ukraini [Epizootological and epidemiological aspects of leptospirosis in Ukraine]. Kiiv [in Ukrainian].

3. Stojanova, H.A. et al. (1993). Sobaki kak vozmozhnyj istochnik leptospiroza u ljudej [Dogs as a possible source of leptospirosis in humans]. Zhurn. mikrobiol. - Journal. Microbiology, 6, 46-48 [in Russian].

4. Javors'kij, I.G. et al. (2002). Gemoragichnij sindrom pri leptospirozi [Hemorrhagic syndrome with leptospirosis]. Infekcijni hvorobi-Infectious diseases, 1, 22-25.

5. Gorodin, V.N. et al. (2004). Sovremennye aspekty gemostaziologicheskih narushenij i vozmozhnosti ih korrekcii pri tjazhelyh formah leptospiroza [Modern aspects of hemostatic disorders and the possibility of their correction in severe forms of leptospirosis]. Anesteziologija $i$ reanimatologija - Anesthesiology and reanimatology, 3, 24-28 [in Russian].

6. Avdeeva, M.G. (1997). Leptospiroz kak zabolevanie s prolongirovannym oslozhnennym techeniem (immunopatogenez, diagnostika, prognoz, lechenie, reabilitacija) [Leptospirosis as a disease with prolonged complicated course (immunopathogenesis, diagnostics, prognosis, treatment, rehabilitation)]. Extended abstract of Doctor's thesis. Moscow [in Russian].

\section{УДК: 636.09:615.37-581.192.7}

ТЮТЮН C.M., e-mail: anaerobsveta@ukr.net,

ГОРБАТЮК О.І., канд. вет. наук, доц., e-mail: goroliva@ukr.net,

АНДРІЯЩУК В.О., канд. вет. наук, e-mail: and_valentina@hotmail.com,

РИЖЕНКО Г.Ф., канд. біол. наук, доц., e-mail: anaerob12@ukr.net,

УХОВСЫКА Т.М., канд. вет. наук, e-mail: tanyavet@ukr.net,

ЖОВНІР О.М., канд. вет. наук, e-mail: Zhovnir73@ukr.net,

Інститут ветеринарної медициини НААН

\section{ВПЛИВ СТП (СТИМУЛЮЮЧОГО ТКАНИННОГО ПРЕПАРАТУ) НА ФАГОЦИТАРНУ АКТИВНІСТЬ КРОВІ У ЩЕПЛЕНИХ СВИНЕЙ}

В статті викладений аналіз результатів досліджень показників природного клітинного захисту у щеплених поросят окремо та на тлі застосування імуномодулюючого препарату «СТП». За рівнем показників фагочитарної активності та інтенсивності фагоцитозу виявлене значне підвищення захисної фагоцитарної функиії організму поросят та активізацію формування імунної відповіді організму після внутрішньом'язових ін'єкцій «СТП» перед вакциначією поросят.

Ключові слова: природна резистентність, фагоцитарна активність, фагоцитарне число, інтенсивність фагоцитозу, імунний статус. 
Вступ. У системі заходів, спрямованих на захист тварин від збудників бактеріальних інфекцій, пріоритетним напрямком є специфічна профілактика. Її ефективність залежить не лише від якості вакцинних препаратів, але й від рівня імунного статусу організму [1-4]. Відомо, що на стан імунної системи тварин впливають біотичні та абіотичні фактори зовнішнього середовища. В умовах сучасного ведення тваринництва на організм тварин постійно впливає комплекс стресових факторів, пов'язаних із технологією їхнього вирощування, утримання, догляду i годівлі. Вони негативно впливають на мобільність пристосувально-адаптаційних механізмів організму і призводять до зниження його природної резистентності. Ці питання $є$ актуальними нині, оскільки організм тварин, особливо молодняка, не в змозі швидко та адекватно відповідати на подразники, тому потребує корекції, яка можлива за застосування нових ефективних препаратів для стимуляції факторів природної резистентності, в т. ч. і тканинних [5-9].

Метою роботи було вивчити та провести порівняльний аналіз показників опсоно-фагоцитарної реакції крові щеплених поросят окремо і за попереднього застосування імуномодулюючого засобу «СТП».

Матеріал i методи досліджень. Експериментальні дослідження проведені на базі фермерського господарства «Бастіон» Летичівського р-ну, Хмельницької обл. та лабораторії анаеробних інфекцій ім. В. Риженка IBM HAAH.

Для проведення експерименту за принципом пар-аналогів було сформовано дві групи клінічно здорових поросят - контрольну і дослідну, по 5 гол. поросят у кожній, віком 50 діб. Середня жива вага тварин контрольної

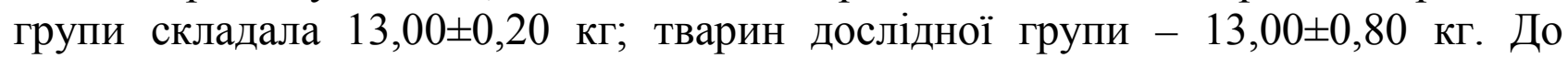
проведення щеплень, через 7 i 14 діб тваринам дослідної групи було застосовано імуномоделюючий засіб «СТП» у вигляді внутрішньом'язових ін'єкцій у дозі по 2,0 см³. Після цього всі поросята були щеплені інактивованою вакциною «Гемофілосан» проти гемофільозу свиней у дозах: по 2,0 за першої та по 3,0 см 3 за повторної імунізації. Кожну групу тварин утримували в окремих клітках. Тварини перебували в однакових умовах щодо годівлі та догляду.

Науково-виробничий експеримент складався із двох періодів підготовчого, тривалістю 14 діб і облікового, тривалістю 56 діб.

Зразки проб крові для досліджень відбирали перед проведенням досліджень, через 14 діб після першої і 14 та 28 діб після повторної імунізації поросят.

Гематологічні дослідження проводили 3 метою визначення загальної кількості лейкоцитів; виведення лейкограми для визначення відносної i абсолютної кількості лімфоцитів; визначення показників опсоно-фагоцитарної реакції (ОФР) для встановлення рівня фагоцитарної активності (ФА) крові - за загальноприйнятими методиками за описом В.I. Левченка та А.М. Нікітенка $[10,11]$. 
Статистичну обробку одержаних результатів досліджень проводили із використанням програми «Excel 97» для Windows (Т.Ф. Лакін, 1990). Критерії вірогідності визначали по Стьюденту із урахуванням порогу вірогідності [12].

Результати досліджень та їх обговорення. Тканинні препарати, проникаючи через клітинні мембрани i біологічні бар'єри у внутрішньоклітинне середовище, відновлюють і підсилюють метаболічні процеси, мінеральний обмін речовин у тканинах i органах та швидко елімінують із організму через сечовидільні шляхи [7]. Результати гематологічних досліджень у поросят, яким перед щепленнями інактивованою вакциною «Гемофілосан» проти гемофільозу свиней застосовували тканинний препарат «СТП», свідчать про його позитивний вплив на організм тварин та більш інтенсивну стимуляцію клітинної ланки імунітету, оскільки абсолютна кількість лімфоцитів зростала вірогідно на 13,7\% (p<0,05), порівняно 3 показниками їхнього вмісту у тварин контрольної групи (табл. 1).

Табличя 1

Результати досліджень деяких гематологічних та показників ОФР крові щеплених поросят після застосування тканинного препарату «СТП», $\mathbf{M} \pm \mathbf{m}, \mathbf{n}=\mathbf{5}$

\begin{tabular}{|c|c|c|c|c|c|c|}
\hline \multirow{3}{*}{$\begin{array}{l}\text { № } \\
\text { п/ா/ }\end{array}$} & \multirow{3}{*}{ Показники } & \multirow{3}{*}{$\begin{array}{c}\text { Група } \\
\text { тварин }\end{array}$} & \multirow{3}{*}{$\begin{array}{c}\text { Початкові } \\
\text { дані }\end{array}$} & \multicolumn{3}{|c|}{$\begin{array}{c}\text { Показники після щеплення тварин, } \\
\text { через діб }\end{array}$} \\
\hline & & & & \multirow{2}{*}{$\begin{array}{c}\text { першого } \\
14\end{array}$} & \multicolumn{2}{|c|}{ повторного } \\
\hline & & & & & 14 & 28 \\
\hline \multirow{2}{*}{1.} & \multirow{2}{*}{$\begin{array}{l}\text { Вміст загальних } \\
\text { лейкоцитів, Т/л }\end{array}$} & контрольна & $13,733 \pm 0,54$ & $16,540 \pm 1,40$ & $15,800 \pm 1,88$ & $17,300 \pm 1,40$ \\
\hline & & дослідна & $16,783 \pm 0,24$ & $13,267 \pm 0,75$ & $16,138 \pm 1,66$ & $17,985 \pm 0,91$ \\
\hline \multirow{2}{*}{2.} & \multirow{2}{*}{$\begin{array}{l}\text { Лейкограма, \%: } \\
\text { лімфоцити }\end{array}$} & контрольна & $63,80 \pm 3,00$ & $55,40 \pm 1,40$ & $65,40 \pm 2,60$ & $64,00 \pm 1,20$ \\
\hline & & дослідна & $68,80 \pm 3,40$ & $56,00 \pm 1,60$ & $55,60 \pm 3,60$ & $67,20 \pm 2,60$ \\
\hline \multirow[b]{2}{*}{3.} & \multirow{2}{*}{$\begin{array}{l}\text { Абсолютна кількість } \\
\text { лімфоцитів, Т/л }\end{array}$} & контрольна & $10,025 \pm 0,39$ & $9,163 \pm 0,82$ & $10,333 \pm 1,55$ & $11,072 \pm 1,17$ \\
\hline & & дослідна & $11,568 \pm 0,75$ & $7,430 \pm 0,53$ & $8,973 \pm 0,73$ & $\begin{array}{c}12,825 \pm 0,91 \\
*\end{array}$ \\
\hline \multirow{6}{*}{4.} & \multirow{2}{*}{$\begin{array}{l}\text { Показники ОФР: } \\
\text { ФА }\end{array}$} & контрольна & $48,4 \pm 4,00$ & $48,8 \pm 2,80$ & $57,0 \pm 2,70$ & $47,40 \pm 3,40$ \\
\hline & & дослідна & $53,8 \pm 4,00$ & $47,8 \pm 2,20$ & $51,4 \pm 4,00$ & $\begin{array}{c}53,40 \pm 1,20 \\
*\end{array}$ \\
\hline & \multirow[b]{2}{*}{ ФI } & контрольна & $1,50 \pm 0,04$ & $2,90 \pm 0,40$ & $2,60 \pm 0,14$ & $3,30 \pm 0,32$ \\
\hline & & дослідна & $1,60 \pm 0,04$ & $2,50 \pm 0,14$ & $2,50 \pm 0,20$ & $\begin{array}{l}3,80 \pm 0,38 \\
*\end{array}$ \\
\hline & \multirow[b]{2}{*}{$\Phi Ч$} & контрольна & $0,40 \pm 0,04$ & $0,70 \pm 0,08$ & $0,70 \pm 0,08$ & $0,80 \pm 0,12$ \\
\hline & & дослідна & $0,40 \pm 0,04$ & $0,60 \pm 0,10$ & $0,60 \pm 0,06$ & $\begin{array}{c}1,00 \pm 0,08 \\
* *\end{array}$ \\
\hline
\end{tabular}

Примітки: * $-\mathrm{p}<0,05 ;{ }^{* *}-\mathrm{p}<0,01$, порівняно із показниками тварин контрольної групи.

ФА найбільше притаманна сегментоядерним нейтрофілам - мікрофагам та у не значній мірі - моноцитам, лімфоцитам, еозинофілам, які створюють моноцитарно-фагоцитарну систему фагоцитів.

Бактерії адсорбуються на поверхні нейтрофілів, тому кількісне зростання активних мікрофагів вказувало на стимуляцію природного клітинного захисту організму.

Аналіз одержаних результатів свідчив про те, що до початку досліду різниця між показниками ФА, фагоцитарного числа (ФЧ) та інтенсивності 
фагоцитозу (ФІ) у дослідних і контрольних тварин суттєво не відрізнялася. У поросят, яким перед щепленнями інактивованою вакциною «Гемофілосан» проти гемофільозу свиней, застосовували тканинний препарат «СТП», спостерігалося зростання кількості активних нейтрофілів (ФА) на рівні 11,8\% $(\mathrm{p}<0,05)$ вірогідно, порівняно із показниками тварин контрольної групи [13]. Оскільки фагоцитоз є одним із основних механізмів природної резистентності та обов’язковим ланцюгом індукції за формування імунітету, зростання кількісного вмісту активних нейтрофілів вказує на прискорення формування імунної відповіді організму після застосування тканинного препарату «СТП» перед щепленнями.

Зростання показників ФЧ свідчило про активізацію імунної системи, оскільки після ін'єкцій тканинного препарату «СТП» у щеплених поросят величина ФЧ була вищою вірогідно на 20,0\% (p<0,01), порівняно з показниками у вакцинованих поросят без застосування стимулюючого засобу.

За комплексного застосування препарату «СТП» і вакцинації тварин інтенсивність фагоцитозу (ФI) зростала вірогідно на 13,2\% (p<0,05), порівняно 3 показниками щеплених поросят контрольної групи, що свідчило про підвищення захисної здатності нейтрофілів та прискорення імунної відповіді організму.

Висновки та перспективи подальших досліджень. Встановлено, що застосування «СТП» перед вакцинацією поросят підвищує захисні фагоцитарні функції організму, що засвідчено зростанням ФА вірогідно на $11,8 \%(\mathrm{p}<0,05)$,

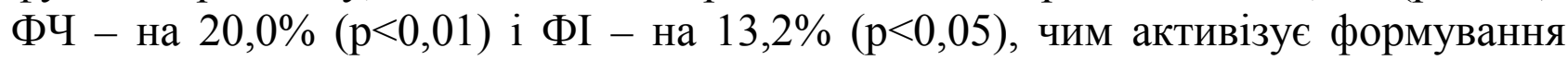
імунної відповіді організму на введений антиген.

Перспективи досліджень направлені на удосконалення тканинного препарату «СТП» шляхом введення до його складу наночастинок заліза і міді в якості біотичних мікроелементів для подолання їхнього дефіциту в організмі поросят та вивчення впливу удосконаленого препарату на показники природної резистентності.

\section{СПИСОК ЛІТЕРАТУРИ}

1. Чумаченко В.Ю. Лікування та профілактика захворювань тварин з урахуванням їх імунного статусу / В.Ю. Чумаченко, В.В. Чумеченко, Н. Бойко // Вет. мед. України. - 2003. № 3. - С. 27-28.

2. Квачов В.Г. Імунологічні та біохімічні підходи до інтегральної оцінки здоров'я тварин / В.Г. Квачов, Т.О. Сокирко // Ветеринарна біотехнологія. - 2006. - № 9. - С. 104-113.

3. Риженко В.П. Теоретичне і експериментальне обгрунтування розробки нових вакцин / В.П. Риженко, Г.Ф. Риженко, О.І. Горбатюк та ін. // Ветеринарна біотехнологія. 2008. - № 13 (1). - С. 51-53.

4. Побірський М.М. Методи корекції імунного статусу корів і новонароджених телят / М.М. Побірський // Ветеринарна біотехнологія. - 2008. - № 13. - С. 136-138.

5. Нікітенко А.М. Інтенсивність росту і якість отриманої продукції свиней при застосуванні структурованих імуномоделюючих препаратів / А.М. Нікітенко, В.П. Лясота, В.В. Малина та ін. // Мясное дело. - 2008. - № 3. - С. 70-73.

6. Землянская 3.3. Вакцинация телят против сальмонеллеза на фоне применения иммуномодулирующих препаратов / 3.3. Землянская, З.А. Литвинова // Вет. медицина. 2008. - № 2. - C. 25-28. 
7. Риженко В.П. Вплив стимулюючого тканинного препарату «СТП» на імунобіологічні реактивність організму поросят за щеплення проти гемофільозу / В.П. Риженко, Г.Ф. Риженко, О.І. Горбатюк та ін. // Ветеринарна біотехнологія. - 2012. № 20. - C. 142-150.

8. Бєлік С.M. Розробка та ефективність препарату 3 імуностимулюючими властивостями (СТП) / С.М. Бєлік та ін. // Ветеринарна біотехнологія. - 2009. - № 15. C. $40-47$.

9. Максимюк Н.Н. О преимуществах ферментативного способа получения белковых гидролизатов / Н.Н. Максимюк, Ю.В. Марьяновская // Фундаментальные исследования. 2009. - № 1. - С. 34-35.

10. Дослідження крові тварин та клінічна інтерпретація результатів: методичні рекомендації / В.І. Левченко, В.М. Соколюк, В.М. Безух та ін. - Біла Церква, 2002. C. 27-31.

11. Методи дослідження природної резистентності свиней: методичні рекомендації / А.М. Нікітенко, В.П. Лясота, В.В. Малина та ін. - Біла Церква - Київ - Львів, 2004.- С. 6163.

12. Ойвин И.А. Статистическая обработка результатов экспериментальных исследований / И.А. Ойвин // Патологическая физиология и экспериментальная терапия. 1960.- № 4.- С. 396-401.

13. Патент № 4626 Україна, МПК А 61 К 9/08. Стимулюючий тканинний препарат 3 імуностимулюючими властивостями для тварин і птиці (СТП). В.П. Риженко, В.В. Риженко, С.М. Бєлік, В.О. Андріящук, О.М. Жовнір, Н.А. Теплюк, П.П. Каменчук); IBM УААН. - NU 200605687; Заявлено 24.05.2006; Опубл. 15.01.2007, Бюл. № 1. - 6 с.

14. Тимчасова настанова по застосуванню тканинних препаратів 3 імуностимулюючими властивостями «СТП-1», «СТП-2», «СТП-3», «СТП-4», «СТП-5»; затверд. Головою Держдепартаменту ветеринарної медицини 24.05.2005 p.

ВЛИЯНИЕ СТП (СТИМУЛИРУЮЩЕГО ТКАНЕВОГО ПРЕПАРАТА) НА ФАГОЦИТАРНУЮ АКТИВНОСТЬ КРОВИ У ПРИВИТЫХ ПОРОСЯТ / ТюТюН С.Н., Горбатюк О.И., Андриящук В.А., Рыженко Г.Ф., Уховская Т.Н., Жовнир А.М.

В статье изложен анализ результатов исследований показателей естественной клеточной защиты у привитых поросят отдельно и на фоне применения иммуномодулирующего препарата «СТП». По уровню показателей фагоцитарной активности и интенсивности фагоцитоза установлено значительное увеличение зашитной фагоцитарной функции организма поросят и активизацию формирования иммунного ответа организма после внутримышечных инъекций «СТП» перед прививками поросят.

Ключевые слова: естественная резистентность, фагоцитарная активность, фагоичитарное число, интенсивность фагоџитоза, иммунный статус.

THE EFFECT OF STP (STIMULATING TISSUE PREPARATION) ON THE PHAGOCYTIC ACTIVITY OF BLOOD IN VACCINATED PIGS / Tiutiun S.N., Gorbatiuk O.I., Andriyaschuk V.A., Ryzhenko G.F., Ukhovska T.N., Zhovnir A.M.

Introduction. The effectiveness of preventive vaccinations directly depends on the level of the immune status of the organism. Complex of stress factors associated with the technology of pigs growing, maintenance, care and feeding have negative influence and lead to a decrease of the natural resistance. The relevance of this issue based in its correction using effective means to stimulate factors of natural resistance, including tissue preparations. 
The goal of the work was to study and carry out comparative analysis of the opsonophagocytic assay (OPA) of vaccinated piglets' blood with and without previous application of the immunomodulating preparation "STP".

Materials and methods. Studies were carried out on 50 days old piglets, which were divided into control and experimental groups of animals. The piglets of the experimental group were vaccinated against Glasser's disease with the "Hemofilosan" vaccine along with the application of immunomodulating preparation "STP" to increase the indices of the natural resistance of animals.

Results of research and discussion. The results of hematological studies of piglets vaccinated with the Hemofilosan vaccine along with the tissue preparation "STP" confirmed the intense stimulation of the cellular immunity, as the absolute number of lymphocytes increased significantly by $13.7 \%(p<0.05)$ compared with this parameters of the control group. OPA showed significant increase in the number of active neutrophils $(P A)$ at the level of $11.8 \%(p<0.05)$, phagocytosis number $(P N)$ was significantly higher by $20.0 \%(p<0.01)$ and the phagocytosis intensity $(P I)$ increased significantly by $13.2 \%(p<0.05)$ compared with the animals of the control group.

Since phagocytosis is one of the main mechanisms of natural resistance and an obligatory chain of induction of the immune development, therefore the increasing in the number of active neutrophils, number of phagocytosed cell and phagocytosis intensity indicated the acceleration of the immune response development after application of the tissue preparation "STP" before vaccination.

Conclusion and prospects further research. STP application before vaccination of piglets increases the protective phagocytic function of their organism, which is confirmed by the significant increase in PA by 11.8\% ( $<0.05)$, PN by 20.0\% (p<0.01) and PI by $132 \%(p<0.05)$, which activated the immune response development against the introduced antigen.

Prospects of the researches will be focused on the introduction of the iron and copper nanoparticles to the preparation STP content as biotic microelements to prevent their deficiency in the pigs' organism and to study of the preparation effect on the indices of natural resistance.

Keywords: natural resistance, phagocytic activity, phagocytic number, phagocytosis intensity, immune status.

\section{REFERENCES}

1.Chumachenko, V.Ju., Chumechenko, V.V., \& Bojko, N. (2003). Likuvannja ta profilaktyka zahvorjuvan' tvaryn z urahuvannjam i'h imunnogo status [Treatment and prevention of animal diseases based on their immune status]. Vet. med. Ukrai'ny - Veterinary medicine of Ukraine, 3, 27-28 [in Ukrainian].

2.Kvachov, V.G., \& Sokyrko, T.O. (2006). Imunologichni ta biohimichni pidhody do integral'noi' ocinky zdorov'ja tvaryn [Immunological and biochemical approaches to integrated assessment of animal health]. Veterynarna biotehnologiia - Veterinary biotechnology, 9, 104-113 [in Ukrainian].

3.Ryzhenko, V.P., Ryzhenko, G.F., Gorbatjuk, O.I. [et al.]. (2008). Teoretychne i eksperymental'ne obg'runtuvannja rozrobky novyh vakcyn [Theoretical and experimental substantiation of the development of new vaccines]. Veterynarna biotehnologiia - Veterinary biotechnology, 13(1), 51-53 [in Ukrainian].

4.Pobirs'kyi, M.M. (2008). Metody korekcii' imunnogo statusu koriv i novonarodzhenyh teljat [Methods of immune status correction of cows and newborn calves]. Veterynarna biotehnologiia - Veterinary biotechnology, 13(1), 136-138 [in Ukrainian].

5. Nikitenko, A.M., Ljasota, V.P., Malyna, V.V. [et al.]. Intensyvnist' rostu i jakist' otrymanoi' produkcii' svynej pry zastosuvanni strukturovanyh imunomodeljujuchyh preparative [Intensity of growth and quality of obtained pig production under application of structured immunomodulating preparations]. Miasnoe delo - Meat business, 3, 70-73 [in Ukrainian].

6.Zemljanskaja, Z.Z., \& Lytvynova, Z.A. (2008). Vakcinacija teljat protiv sal'monelleza na fone primenenija immunomodulirujushhih preparatov [Vaccination of calves against salmonellosis 
using additionally immunomodulating preparations]. Vet. Medicina - Vet. Medicine, 2, 25-28 [in Russian].

7.Ryzhenko, V.P., Ryzhenko, G.F., Gorbatjuk, O.I. [et al.]. (2012). Vplyv stymuljujuchogo tkanynnogo preparatu «STP» na imunobiologichni reaktyvnist' organizmu porosjat za shheplennja proty gemofil'ozu [Influence of stimulating tissue preparation "STP" on immunobiological reactivity of pig at vaccination against Glasser's disease]. Veterynarna biotehnologiia - Veterinary biotechnology, 20, 142-150 [in Ukrainian].

8. Bielik, S.M. [et al.]. (2009). Rozrobka ta efektyvnist' preparatu z imunostymuljujuchymy vlastyvostjamy (STP) [Designing and effectiveness of the preparation with immunostimulating properties (STP)]. Veterynarna biotehnologiia - Veterinary biotechnology, 15, 40-47 [in Ukrainian].

9. Maksimjuk, N.N., \& Mar'janovskaja, Ju.V. (2009). O prepimushhestvah fermentativnogo sposoba poluchenija belkovyh gidrolizatov [On the advantages of the enzymatic process for the production of protein hydrolysate]. Fundamental'nye issledovanija - Fundamental researches, 1, 3435 [in Russian].

10. Levchenko, V.I., Sokoljuk, V.M., Bezuh, V.M. [et al.]. (2002). Doslidzhennja krovi tvaryn ta klinichna interpretacija rezul'tativ [Animal blood studies and clinical interpretation of the results]. Guidelines. Bila Cerkva [in Ukrainian].

11. Nikitenko, A.M., Liasota, V.P., Malyna, V.V. [et al.]. (2004). Metody doslidzhennja pryrodnoi' rezystentnosti svynej [Methods of study of natural resistance in pigs]. Guidelines. Bila Cerkva, Kyi'v, L'viv [in Ukrainian].

12. Ojvin, I.A. (1960). Statisticheskaja obrabotka rezul'tatov jeksperimental'nyh issledovanii [Statistical processing of the results of experimental studies]. Patologicheskaja fiziologija $i$ jeksperimental'naja terapija - Pathological physiology and experimental therapy, 4, 396-401 [in Russian].

13. Ryzhenko, V.P., Ryzhenko, V.V., Bjelik, S.M., Andrijashhuk, V.O., Zhovnir, O.M., Tepljuk, N.A., \& Kamenchuk, P.P. (2007). Stymuljujuchyj tkanynnyj preparat z imunostymuljujuchymy vlastyvostjamy dlja tvaryn i ptyci (STP) [Stimulating tissue preparation with immune stimulating properties for animals and poultry (STP)]. Patent no. 4626 of Ukraine [in Ukrainian].

14. Tymchasova nastanova po zastosuvannju tkanynnyh preparativ z imunostymuljujuchymy vlastyvostjamy «STP-1», «STP-2», «STP-3», «STP-4», «STP-5» [Use of tissue preparations with immune stimulating properties “STP-1”, “STP-2”, “STP-3”, “STP-4”, “STP-5”]. Interim guidelines from 24.05.2005. Derzhdepartament veterynarnoi' medycyny [in Ukrainian]. 